Journal of Economics and Behavioral Studies

Vol. 5, No. 6, pp. 336-345, June 2013 (ISSN: 2220-6140)

\title{
Does Economic Growth Lead Employment in South Africa?
}

\author{
Temitope L. A. Leshoro \\ University of South Africa (UNISA), South Africa \\ lesholat@unisa.ac.za
}

\begin{abstract}
This paper adopts the Toda-Yamamoto technique of causality in order to examine the direction of causality between employment and economic growth. This is to investigate whether the increase in the Gross Domestic Product (GDP) translates into increased employment or not and vice versa, in South Africa, using quarterly data from 2000Q1 to 2012Q3. South Africa has been experiencing high and increased growth for the past decade, yet the rate of employment is not significantly high. Meanwhile, the objective of the government, since the first democratic election in 1994, was to increase economic growth along with a reduction in the unemployment rate (BMR, 2011). Although the economy has been experiencing significant success of increased economic growth, it performed poorly in the area of increased employment (BMR, 2011). This study thus seeks to answer the following questions: (1) does it mean that the increase in growth does not translate to the creation of more jobs and (2) is increased economic growth not as a result of increase in employment in South Africa? The results obtained shows that causality does not run from employment to economic growth in South Africa, as the null hypothesis was not rejected at all significant levels. However, Keynes General Theory holds for South Africa, where the empirical result showed that economic growth leads employment. These results support the criticism of 'jobless growth' against South Africa (Kumo, 2012). The paper suggests some policy recommendations for the improvement of employment.
\end{abstract}

Keywords: Causality, Employment, GDP, Toda-Yamamoto, Unemployment rate

\section{Introduction}

Output growth and employment levels, amongst other factors, are used to measure the macroeconomic performance of an economy. In the case of South Africa, despite the high level of economic growth, there are concerns on the high level of unemployment, which makes its performance measure somewhat unpredictable. The objective of the South African government, since the first democratic election in 1994, was to increase economic growth along with a reduction in the rate of unemployment (BMR, 2011). Although, there has been a significant change in the economy since 2000, where inflation was well within the target band coupled with increased economic growth, it performed poorly in the area of increased employment (BMR, 2011). In its quest to create more jobs and hence eradicate poverty and inequality, the government introduced 4 programs over the post-apartheid period between 1994 and 2009, namely, Reconstruction and Development Program (RDP), the Growth Employment and Redistribution Program (GEAR), the Accelerated and Shared Growth Initiative of South Africa (AsgiSA) and the last one is the New Growth Path (NGP) in 2010. However, between the period 2008 and 2010, the country lost over a million jobs with only about a quarter of a million jobs created in the period after the economic downturn in 2011 (African Economic Outlook, 2012). After the episode of job losses, Gross Domestic Product (GDP) increased from 2.9\% in 2010 to 3.11\% in 2011, consumption grew by $3.5 \%$ in 2011 and unemployment fell from $25 \%$ in the third quarter of 2011 to $23.9 \%$ by the end of the year. Despite the increase in GDP, the country remains one of the most unequal societies in the world (African Economic Outlook, 2012), where about half of South African youths, aged between 15 and 24 are unemployed. Even though there were massive job losses, a successful performance was reported in the economy (African Economic Outlook, 2012), which could be owing to other factor(s), such as macroeconomic stability and not as a result of employment. With all these achievements, total unemployment was on the rise, this means that the macroeconomic stability was not sufficient to create more jobs and therefore lessen unemployment. Table 1 shows the unemployment rates of some of the countries in the Southern African region. Although the rate of unemployment in South Africa is lower than in other neighboring countries, its 
unemployment rate is still high whereas South Africa is seen as the powerhouse of Africa and the fastestgrowing economy in Africa (IMF, 2012).

Table 1: Rate of unemployment in selected Southern African countries

\begin{tabular}{lll}
\hline Country & Year & Unemployment rate \\
\hline South Africa & $2008(2011)$ & $22.9 \%(29.8 \%)$ \\
Botswana & 2006 & $17.6 \%$ \\
Lesotho & 2008 & $25.3 \%$ \\
Namibia & 2008 & $37.6 \%$ \\
Swaziland & 1997 & $22.5 \%$ \\
Zambia & 2009 & $23.8 \%$ \\
\hline
\end{tabular}

Source: World Bank, World Development Indicators, 2011.

Furthermore, from a policy perspective, the level of employment depends on both the economic growth and the level at which the economy can absorb labor (Altman, 2003). This means that even if a country's economic growth increases considerably, it should be accompanied with an increased demand for workers. But there is no guarantee that increased economic growth can increase the labor-absorption. This is partly due to the fact that employers prefer capital to labor in the production process (BMR, 2011). Therefore, the contribution of this study to literature is to determine the direction of causality between employment and economic growth in South Africa, seeing that the country records somewhat high levels of economic growth with little or no increase in the much-needed jobs in order to decrease unemployment. This, thus, poses the following objective questions: Does the increase in growth not translate into an increase in employment, albeit small? Is the increase in economic growth not consequently from employment increases in South Africa? In addition, Figure 1 shows the growth rates of employment and real GDP, as a measure of economic growth, in South Africa over the period 1995 to 2011. This figure gives a better picture than depicting the actual values of these variables. The rate of growth of employment was increasing more than the growth rate of GDP in the early years of post-apartheid era of 1994, except in 1997 where a negative growth was reported. In some cases, the increase in the growth rate of employment was more than triple economic growth. This trend continued up until around 2000. The change in the growth rate of employment took a different turn from 2001 to 2003 experiencing negative growth rates; this was also the case during the 2009 2010 , as a result of the economic recession of 2008.

Figure 1: Real GDP and Employment Growths in South Africa (1995 - 2011)

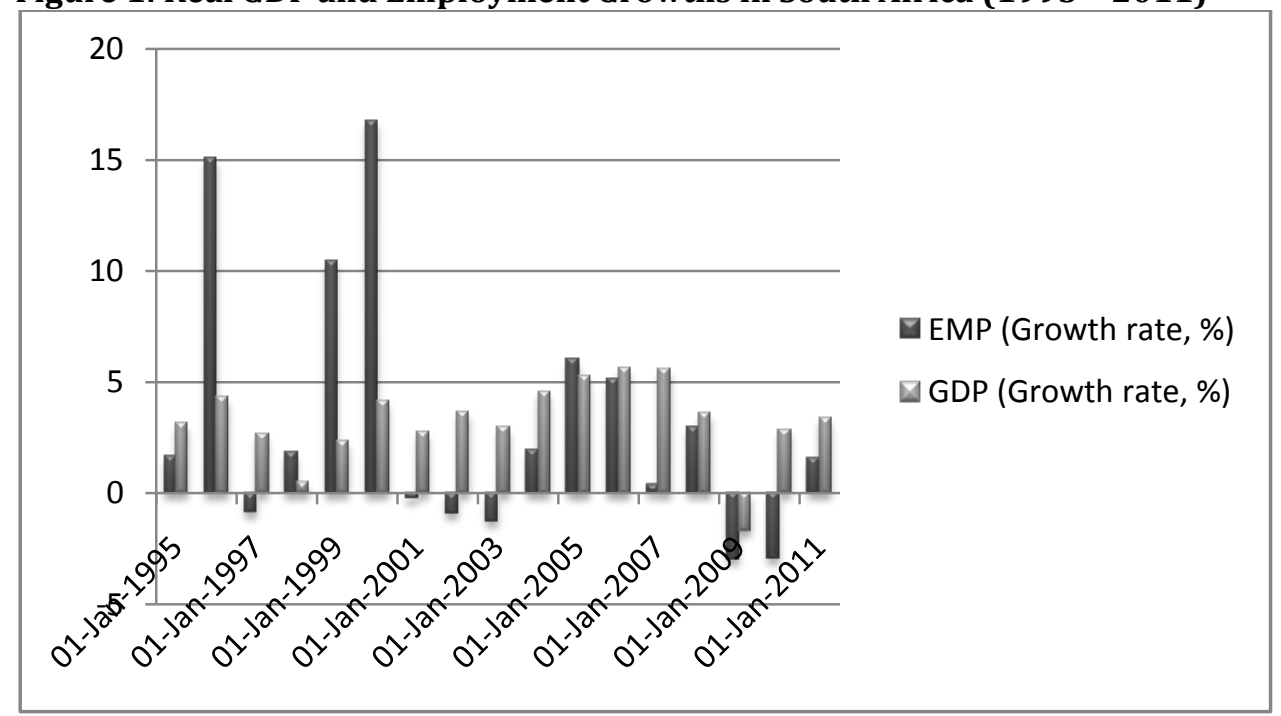

Source: International Monetary Fund (IMF) IFS Database. 
However, between 2004 and 2008, South Africa experienced positive growth rates, with the rate of employment increasing alongside the increased GDP. There was a decline in the rate of GDP and employment during the period of economic downturn when many jobs were lost; this does not apply only to South Africa, as many countries around the globe experienced the same recession. In general, the figure shows that there was a positive relationship between the 2 variables during these periods, 1995 - 1996, 1999 - 2001; 2004 2005 as well as in 2011, while a negative relationship was depicted in the other periods. The rest of the paper is organized as follows: the following section reviews some recent literature on different relationships between employment, unemployment and economic growth; data and the method of estimation are provided in section 3, followed by the results in section 4 . Section 5 discusses the robustness test, which was carried out to validate the robustness of the results in section 4 . The study concludes with some thoughts about policy recommendations in section 6 .

\section{Review of Literature}

The following section reviews the employment-growth nexus theory. The empirical studies carried out in determining the relationship between employment or unemployment and economic growth in terms of the impacts, employment elasticities of growth and the causality between employment and economic growth are also reviewed. According to Keynes (1936) in The General Theory, he proposed that changes in employment results from changes in GDP through the aggregate demand (AD), as opposed to the Classical theory of price of labor determining employment. Keynes argued that equilibrium exists when full-employment is present in the economy. His further argument related the effect of the relationship between savings and investment on aggregate demand and employment. While savings and investment are both driven by interest rate, he argued that they are not necessarily always equal. Increased savings can increase investment, but if the expected rate of returns on investment is low, the level of investment will fall and as a result aggregate demand will fall. The insufficient demand will therefore result in equilibrium which will be less than full employment. Thus, the change in GDP through the changes in aggregate demand determines the level of employment. Hence, Keynes theory supports the notion that an increase in GDP should translate into increased employment until equilibrium is achieved. Keynes also stated that unemployment results from low growth of effective demand, and in the presence of effective demand, employment increases (Ewing, 1999). This reinforces his argument that GDP, through the change in aggregate demand, determines the level of employment. For economic growth to lead employment in an economy it should be labor-absorptive in nature (BMR, 2011; Hansen, 2013). This suggests that there exists a direct relationship between employment and economic growth and that the direction of causality runs from economic growth to employment. While many studies focused on the unemployment, its determinants and its impact on economic growth (Eita \& Ashipala, 2010; Biyase \& BongaBonga, 2007; Adebayo \& Ogunrinola, 2006; Omotor \& Gbosi, 2006; Oladeji, 1994), others examined the relationship between employment and GDP (Rad, 2011; Yogo, 2008; Swane \& Vistrand, 2006; Walterskirchen, 1999). However, some studies estimated the employment elasticities of growth (Sodipe \& Ogunrinola, 2011; Sawtelle, 2007; Pandalino \& Vivarelli, 1997) using various techniques and others measured the direction of causality between these variables (Kumo, 2012; and Asari et al., 2011; Caporale \& Škare, 2011).

Eita \& Ashipala (2010) estimated the determinants of unemployment in Namibia and found positive relationship between employment and total GDP as well as between employment and GDP of the manufacturing sector. They also found negative relationship between investment and unemployment; this means that as investment increases, unemployment decreases while employment increases. While estimating the relationship between GDP growths on employment, Rad (2011) found that the high growth rates experienced by Jordan did a little in creating new productive jobs. It was concluded that the government will need to move from low value-added production and exports to a sector that is more sustainable in terms of quality and wages. Other studies that considered the relationship between employment and economic growth are Walterskirchen (1999), where the relationship between employment, unemployment and economic growth in the European Union (EU) countries was analyzed using both time series data for each country and panel data for all the countries together. The result showed that there existed positive relationships between the levels of employment and economic growth. Landmann (2002) also found a strong and positive relationship between employment and productivity. In the study carried out by Biyase \& Bonga-Bonga (2007) on testing the jobless growth in South Africa, they found that an increase in output leads to a small increase in 
employment, using the Structural Vector Autoregressive (SVAR) technique and their study rejected the idea of jobless growth in South Africa. Meanwhile, Sawtelle (2007) carried out a study on 14 industry sectors' employment in the United States and real GDP over the period 1991 to 2001. The employment elasticities of growth were estimated and compared among the industries by measuring employment against real GDP and also against other variables that affect employment. Ajilore \& Yinusa (2011) also estimated the employment intensity of output growth in Botswana over the sectors and found low sectoral employment intensity. This showed that increase in growth was as a result of increased labour-productivity rather than labouremployment; that is the economy experienced 'jobless-growth'. Along the same line, the study by Osmani (2006) showed low employment elasticity in the manufacturing sector in Asia. Pini (1997) found an increase in the employment elasticities of growth for Germany and Japan, and low elasticities in France and Sweden, while negative employment elasticities were experienced in Italy and Sweden.

There are, however, very few studies that considered the direction of causality between employment and GDP. Some of the studies carried out showed that employment growth leads to a change in economic growth, where Marelli and Signorelli (2010) found that high employment growth in the European Union area causes a slower economic growth. Also, Caporale \& Škare (2011) found causality running from employment to GDP growth in most of the countries when they carried out a panel and country-specific study on 119 countries using VECM and Granger causality test. Some of the country-specific studies include Kumo (2012) and Asari et al. (2011). Asari et al. (2011) found a uni-directional causality running from employment to GDP in the short-run in Malaysia over the period 1982 to 2006. However, Kumo (2012) carried out a causality test among economic growth, infrastructure investment and private and public employment in South Africa using the conventional Granger causality test as well as the autoregressive distributed lag (ARDL) over the period 1960 to 2009. The result obtained failed to reject the null hypothesis that GDP does not granger cause employment in the private and public sectors and employment in these sectors also do not granger cause GDP. The result also showed that investment granger causes GDP growth. After accounting for structural break, the result showed that economic growth granger causes public sector employment but not vice versa. Other studies that found the notion of economic growth leading employment include Phelps (1994) and Ball \& Moffit (2001).

\section{Methodology}

Seeing that there are very few studies carried out on the direction of causality between employment and economic growth; this study contributes immensely to literature, in the area of different methodology and extension of data period. Quarterly data spanning over the period 2000Q1 to 2012Q3 was used, making 51 data points. These are the periods where quarterly employment data is available, but annual employment data is from 1994, hence restricting the overall data point to the period 2000Q1 to 2012Q3. Real GDP is used as a proxy for measuring economic growth and it is measured in millions of rands and employment is measured in thousands. These variables were sourced from the IMF, International Financial Statistics (IFS) database. Given the different ways of estimating the relationship between employment and output growth in many countries, with different estimation methods; this study tests the Keynes theory of employment-growth nexus using a different and more advanced econometric technique. Toda-Yamamoto (T-Y) causality test, rather than the conventional Granger (1969) causality test, will be used to investigate the direction of causality between employment and economic growth in South Africa. It is important to note that causality does not necessarily mean that a variable causes another, but that one variable leads the other. This study utilizes the Toda-Yamamoto test of causality technique which makes use of the Vector Auto regression (VAR). Some of the advantages of this approach over the conventional Granger (1969) causality test include; no requirement for a pre-test of co-integration, the order of integration does not have to be the same and any of the series can be I (0), I (1) or I (2), as long as the order of integration is lower than or equal to the true lag length of the model (Toda \& Yamamoto, 1995; Akcay, 2011). Testing Granger-causality using the conventional $F$-statistics can result in spurious causality, when one or more variables are non-stationary (He \& Maekawa, 1999), but this is not the case for T-Y, where MWald statistics is used and the variables do not necessarily have to be stationary. Other benefits of T-Y causality test are that its results do not suffer from the lag effect and it does not give spurious result with invalid F-test whereas the conventional Granger causality test result changes as the lag length changes (Akcay, 2011). The importance of a country-specific study, as in this case, 
over a cross-country study is the danger in comparison where different countries use different measurements and different definitions of unemployment and labor force (ILO, 2013; Fourie and Burger, 2009:481).

The bivariate causality model of employment and GDP is specified as follows:

$$
\begin{aligned}
& G D P_{t}=\alpha_{0}+\sum_{i=1}^{k+d} \alpha_{1 i} G D P_{t-i}+\sum_{j=1}^{k+d} \alpha_{2 j} E M P_{t-j}+\varepsilon_{t} \\
& E M P_{t}=\psi_{0}+\sum_{i=1}^{k+d} \psi_{1 i} E M P_{t-i}+\sum_{j=1}^{k+d} \psi_{2 j} G D P_{t-j}+v_{t}
\end{aligned}
$$

Where, GDP is the Real Gross Domestic Product as a measure of economic growth, EMP is employment levels, $\alpha$ 's and $\psi$ 's are coefficients, $k$ is the optimal lag order, $d$ is the maximal order of integration of the variables $\left(\mathrm{d}_{\max }\right), \varepsilon_{\mathrm{t}}$ and $v_{\mathrm{t}}$ are error terms. The causality is tested on each variable, for instance in equation 1 , causality is tested from employment to GDP. The null hypothesis for equation 1 therefore is "EMP does not granger cause GDP" if: $H_{0}: \alpha_{2 j}=0$ against its alternative $H_{1}: \alpha_{2 j} \neq 0$. The null hypothesis for equation 2 is "GDP does not granger cause EMP" if: $\mathrm{H}_{0}: \psi_{2 \mathrm{j}}=0$ against its alternative $\mathrm{H}_{1}: \psi_{2 \mathrm{j}} \neq 0$. The Seemingly Unrelated Regression (SUR) method is used to regress each variable on each other, from (1) to $\left(\mathrm{k}+\mathrm{d}_{\max }\right)$. If the coefficient of employment variable in equation $1, \alpha_{2}$, is not statistically significantly different from zero, it means that there is no causality from employment to GDP, and if the coefficient of GDP variable in equation $2, \psi_{2 \mathrm{j}}$, is not statistically significantly different from zero, then GDP does not granger cause employment. However, if $\alpha_{2 j}$ and $\psi_{2 j}$ are statistically significantly different from zero, it means the null hypotheses of no causality will be rejected.

\section{Results and Discussion}

The Phillips-Perron unit root test was used to test for stationarity while the order of integration of each variable is subsequently determined. Table 2 shows the result of the unit root test. We fail to reject the null hypothesis of stationarity of the variables in levels, which means that they are not $\mathrm{I}(0)$, but the null hypothesis was rejected after differencing the employment variable once. This shows that the employment series is integrated of order 1, I(1). However, real GDP only becomes stationary at the second difference, which means that this variable is integrated of order 2, I(2).

Table 2: Phillips-Perron Unit root tests: GDP and EMP

\begin{tabular}{llllllll}
\hline Variables & $\begin{array}{l}\text { Levels } \\
\text { Intercept }\end{array}$ & $\begin{array}{c}\text { Trend \& } \\
\text { Intercept }\end{array}$ & $\begin{array}{l}\text { First difference } \\
\text { Intercept }\end{array}$ & $\begin{array}{r}\text { Trend \& } \\
\text { Intercept }\end{array}$ & $\begin{array}{l}\text { Intercept } \\
\text { Trend \& }\end{array}$ & Conclusion \\
\hline GDP & -0.371 & -1.647 & $-3.150^{* *}$ & -3.116 & $-7.911^{* * *}$ & $-7.743^{* * *}$ & $\begin{array}{l}\text { Non- } \\
\text { stationary }\end{array}$ \\
EMP & -1.164 & -1.811 & $-6.915^{* * *}$ & $-6.834^{* * *}$ & NA & NA & $\begin{array}{l}\text { Non- } \\
\text { stationary }\end{array}$ \\
\hline
\end{tabular}

${ }^{*} 10 \%,{ }^{* *} 5 \%,{ }^{* * *} 1 \%$. Eviews 7 was used for all computations.

Critical values:

Intercept: $1 \%=-3.57 ; 5 \%=-2.92 ; 10 \%=-2.60$, Trend and Intercept: $1 \%=4.16 ; 5 \%=3.50 ; 10 \%=3.18$

Analysis: By author.

Since there is no need to test for the presence of co-integration before carrying out the Toda-Yamamoto causality test, this study moved on to test for causality of each of the variables. The lag length, $\mathrm{k}$, was chosen primarily based on the Akaike Information Criterion (AIC), where a lag of 2 was selected, along with all the other criteria (See Appendix). Using SUR, we run each of the variables on each other with lag from (1) to (4), where 4 was obtained from $\mathrm{k}+\mathrm{d}_{\max }$; $\mathrm{k}$ is the lag length (2 in this case) and $\mathrm{d}_{\max }$ is the maximum order of integration (also 2 in this case) (See table 3). The result of the Toda-Yamamoto causality test is reported in table 3. The null hypothesis of 'no granger causality from employment to GDP', in equation 1, was not rejected. This means that increases in the employment levels do not lead to increases in real GDP. Thus, the objective question of 'whether the increase in economic growth is not as a result of increase in employment' 
is answered by this result. We therefore conclude that the increase in economic growth is not due to the increase in employment.

Table 3: Toda-Yamamoto test of causality

\begin{tabular}{lllllll}
\hline Null hypothesis & $\mathbf{k}$ & $\mathbf{k}+\mathbf{d}_{\max }$ & $\begin{array}{l}\text { MWald } \\
\text { Stats }\end{array}$ & p-value & Decision & Conclusion \\
\hline $\begin{array}{l}\text { EMP does not granger } \\
\text { cause GDP }\end{array}$ & 2 & $2+2=4$ & 1.085 & 0.897 & Not rejected & No causality \\
$\begin{array}{l}\text { GDP does not granger } \\
\text { cause EMP }\end{array}$ & 2 & $2+2=4$ & 13.858 & $0.008^{* * *}$ & Rejected at $1 \%$ & Causality \\
\hline
\end{tabular}

*10\%; **5\%; ***1\%. Eviews 7 was used for all computations.

Analysis: By author

On the other hand, the null of 'no granger causality from GDP to employment' (equation 2) was rejected, at all levels of significance. The result from equation 2 is in line with the Keynes general theory of full employment. The increase in the real GDP is expected to lead to an increase in employment levels, according to this theory, and the result obtained showed that the theory holds in the case of South Africa. This part of the result answered the first objective question of 'whether increases in economic growth translate into increases in employment'. Therefore, we conclude that increased real GDP does lead to an increase in employment in South Africa. The results obtained from the Toda-Yamamoto test of causality showed that there is no causality running from employment to GDP in South Africa, as we failed to reject the null hypotheses that 'employment does not granger cause GDP' at all levels of significance. However, the test of causality from GDP to employment was significant. Hence, we conclude that employment does not lead economic growth but economic growth does lead employment in South Africa. The result obtained is not surprising as it confirms that the increase in GDP of South Africa leads to increased employment, and this agrees with Keynes theory of employment-growth nexus. But, the increase in GDP is not as a result of increased employment, affirming that the country is experiencing jobless growth.

Robustness Test: The test for robustness was carried out by adding extra 2 explanatory variables; these are, gross fixed capital formation (measured in millions of Rand) as a proxy for investment (INV) and lending rate (LDR), which measures the effects of monetary policy on employment creation in South Africa. The importance of the test of robustness is to validate the reliability of the result obtained earlier. The unit root was also tested on the additional explanatory variables. The lending rate is integrated of order 1, I(1), while investment is integrated of order 2, I(2). The result of the unit root test is reported in table 4.

Table 4: Phillips-Perron Unit root tests: GDP, EMP, LDR and INV

\begin{tabular}{llllllll}
\hline Variables & $\begin{array}{l}\text { Levels } \\
\text { Intercept }\end{array}$ & $\begin{array}{l}\text { Trend \& } \\
\text { Intercept }\end{array}$ & $\begin{array}{l}\text { First difference } \\
\text { Intercept }\end{array}$ & $\begin{array}{l}\text { Trend \& \& } \\
\text { Intercept }\end{array}$ & $\begin{array}{l}\text { Second difference } \\
\text { Intercept }\end{array}$ & $\begin{array}{l}\text { Trend \& \& } \\
\text { Intercept }\end{array}$ & Conclusion \\
\hline GDP & -0.371 & -1.647 & $-3.150^{* *}$ & -3.116 & $-7.911^{* * *}$ & $-7.743^{* * *}$ & $\begin{array}{l}\text { Non- } \\
\text { stationary }\end{array}$ \\
EMP & -1.164 & -1.811 & $-6.915^{* * *}$ & $-6.834^{* * *}$ & NA & NA & $\begin{array}{l}\text { Non- } \\
\text { stationary }\end{array}$ \\
LDR & -1.446 & -2.104 & $-3.278^{* *}$ & $-3.231^{*}$ & NA & NA & $\begin{array}{l}\text { Non- } \\
\text { stationary } \\
\text { INV }\end{array}$ \\
\hline & -2.014 & 0.161 & -2.593 & -2.591 & $6.966^{* * *}$ & $-6.803^{* * *}$ & $\begin{array}{l}\text { Non- } \\
\text { stationary }\end{array}$ \\
\hline
\end{tabular}

${ }^{*} 10 \%,{ }^{* *} 5 \%,{ }^{* * *} 1 \%$. Eviews7 was used for all computations.

LDR = Lending Rate; INV = Investment.

Critical values:

Intercept: $1 \%=-3.57 ; 5 \%=-2.92 ; 10 \%=-2.60$, Trend and Intercept: $1 \%=4.16 ; 5 \%=3.50 ; 10 \%=3.18$

Analysis: By author. 
Furthermore, table 5 affirms the result obtained in table 3, where GDP in South Africa leads total employment, but employment does not granger cause GDP. The lag length was selected based on AIC, although all the criteria also chose lag order of 2 , therefore $\mathrm{k}$ is 2 . And since the highest order of integration is 2 , then $d_{\max }$ is also 2. Running the SUR model from (1 to $\mathrm{k}+\mathrm{d}_{\max }$ ), that, is (1) to (4) in this case, the result in table 5 was obtained. The result further shows that the monetary policy, through the effect of lending rate which is determined by the repo rate, does not lead employment-creation. However, changes in investment cause employment to change, but not vice versa. This also supports Keynes argument on the effects of investment on aggregate demand and employment. Thus, investment leads employment in South Africa.

Table 5: Toda-Yamamoto test of causality: Robustness Test

\begin{tabular}{|c|c|c|c|c|c|c|}
\hline Null hypothesis & $\mathbf{k}$ & $\mathbf{k}+\mathbf{d}_{\max }$ & $\begin{array}{l}\text { MWald } \\
\text { Stats }\end{array}$ & p-value & Decision & Conclusion \\
\hline $\begin{array}{l}\text { EMP does not granger } \\
\text { cause GDP }\end{array}$ & 2 & $2+2=4$ & 4.257 & 0.372 & $\begin{array}{l}\text { Not } \\
\text { rejected }\end{array}$ & No causality \\
\hline $\begin{array}{l}\text { INV does not granger } \\
\text { cause GDP }\end{array}$ & 2 & $2+2=4$ & 41.729 & $0.000^{* * *}$ & $\begin{array}{l}\text { Rejected at } \\
1 \%\end{array}$ & Causality \\
\hline $\begin{array}{l}\text { LDR does not granger } \\
\text { cause GDP }\end{array}$ & 2 & $2+2=4$ & 8.863 & $0.064^{*}$ & $\begin{array}{l}\text { Rejected at } \\
10 \%\end{array}$ & Causality \\
\hline $\begin{array}{l}\text { INV does not granger } \\
\text { cause EMP }\end{array}$ & 2 & $2+2=4$ & 8.923 & $0.063^{*}$ & $\begin{array}{l}\text { Rejected at } \\
10 \%\end{array}$ & Causality \\
\hline $\begin{array}{l}\text { GDP does not granger } \\
\text { cause EMP }\end{array}$ & 2 & $2+2=4$ & 9.060 & $0.060^{*}$ & $\begin{array}{l}\text { Rejected at } \\
10 \%\end{array}$ & Causality \\
\hline $\begin{array}{l}\text { LDR does not granger } \\
\text { cause EMP }\end{array}$ & 2 & $2+2=4$ & 2.008 & 0.734 & $\begin{array}{l}\text { Not } \\
\text { rejected }\end{array}$ & No causality \\
\hline $\begin{array}{l}\text { EMP does not granger } \\
\text { cause INV }\end{array}$ & 2 & $2+2=4$ & 2.913 & 0.572 & $\begin{array}{l}\text { Not } \\
\text { rejected }\end{array}$ & No causality \\
\hline $\begin{array}{l}\text { GDP does not granger } \\
\text { cause INV }\end{array}$ & 2 & $2+2=4$ & 20.208 & $0.001^{* * *}$ & $\begin{array}{l}\text { Rejected at } \\
1 \%\end{array}$ & Causality \\
\hline $\begin{array}{l}\text { LDR does not granger } \\
\text { cause INV }\end{array}$ & 2 & $2+2=4$ & 5.395 & 0.249 & $\begin{array}{l}\text { Not } \\
\text { rejected }\end{array}$ & No causality \\
\hline $\begin{array}{l}\text { EMP does not granger } \\
\text { cause LDR }\end{array}$ & 2 & $2+2=4$ & 6.813 & 0.146 & $\begin{array}{l}\text { Not } \\
\text { rejected }\end{array}$ & No causality \\
\hline $\begin{array}{l}\text { INV does not granger } \\
\text { cause LDR }\end{array}$ & 2 & $2+2=4$ & 6.862 & 0.143 & $\begin{array}{l}\text { Not } \\
\text { rejected }\end{array}$ & No causality \\
\hline $\begin{array}{l}\text { GDP does not granger } \\
\text { cause LDR }\end{array}$ & 2 & $2+2=4$ & 0.737 & 0.947 & $\begin{array}{l}\text { Not } \\
\text { rejected }\end{array}$ & No causality \\
\hline
\end{tabular}

*10\%; **5\%; ***1\%. Eviews 7 was used for all computations.

Analysis: By author

The result was further tested for stability and it was found there was no structural break in the model. The CUSUM of squares test examines the stability of a parameter where the cumulative sum of squares lies within the $5 \%$ line of significance (see figure 1). If the cumulative sum of squares lie outside the significant line, the result depicts an unstable model, or that the model exhibits a structural break. Since the line of the cumulative sum of squares is within the $5 \%$ significant line, we therefore conclude that there was no structural break in the model. 
Figure 2: CUSUM of squares test

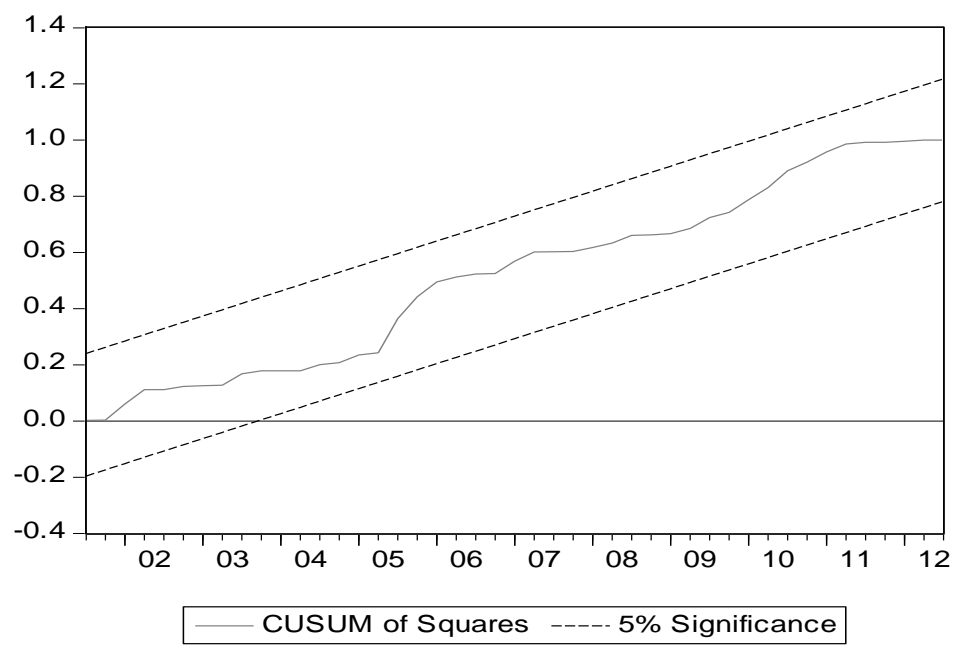

\section{Conclusion and Recommendations}

South Africa has been experiencing increased economic growth for the past decade, yet the rate of employment is not significantly high. Very few studies have investigated the link between employment and economic growth in terms of causality and none, according to our knowledge, investigated such for South Africa, with the same methodology. While some studies considered the employment elasticities on growth in various countries, others tested the impact of employment and unemployment on GDP. This study therefore tested the direction of causality between economic growth proxied by GDP and employment in South Africa, in order to investigate whether or not a change in GDP translates into a change in employment and vice versa. The result obtained agrees with the Keynes General Theory of full employment because economic growth does significantly lead employment. However, the change in employment does not lead economic growth. Thus, there was no uni-directional causality from employment to real GDP in South Africa, as we failed to reject the null hypotheses that 'employment does not granger cause real GDP' at all significant levels. However, we rejected the null hypothesis that 'real GDP does not granger cause employment'. These results support the criticism of growth without employment against South Africa, referred to as 'jobless growth', that is the increase in economic growth is not as a result of increased employment (Kumo, 2012). The results also agree with the Keynes theory of GDP leading employment. The test of robustness carried out further supports our results, and additional observation was made where monetary policy does not cause a change in employment.

Since increased real GDP empirically translates into increased employment, yet the level of employment does not seem to be increasing, then employment could be increased exogenously through the creation of new (small) businesses, rather than absorbing labor into the already existing ones. This will eliminate the demand-side unemployment. Other policies that the government can consider in order to reduce the demandside unemployment are reduction in taxes (the marginal tax rate (individual rate) is currently as high as $40 \%$ in South Africa). The increase in government spending through increase in pay levels in the educational and health sectors could be another policy to consider. One of the major problems that the country faces is that of structural unemployment, where there is a mismatch between workers' skills and the job requirements. In order to improve employment placement, government policy should initiate skills-development program to eliminate the possibility of structural unemployment. Other policies that could be adopted, which will reduce the supply-side unemployment, apart from the education and training as earlier-mentioned, include employment subsidies and reduction of trade union power, which is very strong in South Africa. The initiative of youth employment subsidy, which is underway, is however in the right direction to assist in increasing employment. Further studies can consider a disaggregated employment, where the effect of employment from the formal and informal sectors could be tested on economic growth. An investigation of whether a change in economic growth causes a change in employment in any particular sector and vice versa. 
Considering regional approach whereby the direction of causality is examined for each country could also be an area for further research.

\section{References}

Adebayo, A. \& Ogunrinola, I. O. (2006). Contemporary Dimensions of Unemployment Problem in Nigeria: A Special Challenge under the National Economic Empowerment and Development Strategy. The Nigerian Economic Society.

Ajilore, T. \& Yinusa, O. (2011). An analysis of employment intensity of sectoral output growth in Botswana. Southern African Business Review, 15(2), 26 - 42.

Akcay, S. (2011). The Causal Relationship between Producer Price Index and Consumer Price Index: Empirical Evidence from Selected European Countries. International Journal of Economics and Finance, 3(6), 227 $-232$.

Altman, M. (2003). Jobless or Job Creating Growth? Some preliminary thoughts. Employment and Economic Policy Research Program, Human Sciences Research Council. Paper Presented at the TIPS/ DPRU Annual Forum

Asari, F. F., Mohamad, Z., Alias, T. S., Shamsudin, N., Baharuddin, N. S. \& Kamaruzaman, J. (2011). Multivariate Time Series Analysis on Correlation between Inflation rate and Employment rate with Gross Domestic Product. World Applied Sciences Journal, (Special Issue on Bolstering Economic Sustainability), 61 - 66.

Ball, L. M. \& Moffitt, R. A. (2001). Productivity growth and the Phillips curve. National Bureau of Economic Research, Cambridge, Mass, USA.

Biyase, M. \& Bonga-Bonga, L. (2007). South Africa's growth paradox. DEGIT Conference Papers. www.degit.ifw-kiel.de/papers/degit_12/C012_043.pdf Accessed 3 February 2013.

Bureau of Market Research (BMR). (2011). A broad review of the new growth path framework with a specific emphasis on the feasibility of its proposed targets. http://www.unisa.ac.za/contents/faculties/ems/docs/Press413.pdf Accessed 1 February 2013.

Caporale, G.M. \& Škare, M. (2011). Short- and Long-Run Linkages between Employment Growth, Inflation and Output Growth: Evidence from a Large Panel. Economics and Finance Working Paper Series, No. 11-17.

Eita, J. H. \& Ashipala, J. M. (2010). Determinants of Unemployment in Namibia. International Journal of Business and Management, 5(10), 92-104.

Ewing, B. T. (1999). Employment and economic performance: Jobs, inflation, and growth. Journal of Labor Research, 20(4), 622-624.

Fourie, F. C. N. \& Burger, P. (2009). How to Think and Reason in Macroeconomics. $3^{\text {rd }}$ ed. Juta \& Co. Ltd. Cape Town.

Granger, C. W. J. (1969). Investigating Causal Relationships by Econometric Models and Cross-Spectral Models. Econometrica, 37(3), $424-438$.

Hansen, S. (2013). Weekly Review: Does Employment Really Lag Economic Growth? http://www.nasdaq.com/article/weekly-review-does-employment-really-lag-economic-growthcm171052 Accessed 1 February 2013.

He, Z. \& Maekawa, K. (1999). On spurious Granger causality. Economic letters, 73(3), 307-313.

International Labor Organization (ILO). (2013). Key Indicators of labor market database, The World Bank.

International Monetary Fund (IMF). (2012). Sub-Saharan Africa, Maintaining Growth in an Uncertain World. World Economics and Financial Surveys, Regional Economic Outlook.

Keynes, J. M. (1936). The General Theory of Employment, Interest and Money. London: Macmillan (Reprinted 2007).

Kumo, W. L. (2012). Infrastructure Investment and Economic Growth in South Africa: A Granger Causality Analysis. African Development Bank, Working Paper Series $N^{\circ} 160$, Tunis, Tunisia.

Landmann, O. (2002). Employment, productivity and output growth. ILO, mimeographed.

Marelli, E. \& Signorelli, M. (2010). Employment, productivity and models of growth in the EU. International Journal of Manpower, 31 (7), 732-754.

Oladeji, S. I. (1994). Absorption of Educated Manpower into Nigeria's Informal Sector. National Manpower Board.

Omotor, D. G. \& Gbosi, A. N. (2006). The Dynamics of Productivity and Unemployment Nexus: Implications for Employment Generation in Nigeria. Nigerian Economic Society, 2,177-197. 
Osmani, S. R. (2006). Employment intensity of Asian manufacturing: An examination of recent trends. United Nations Development Programme (UNDP), New York.

Pandalino, S. \& Vivarelli, M. (1997). The Employment Intensity of Economic Growth in the G-7 Countries. International Labor Review, $136(2), 191-213$.

Phelps, E. S. (1994). Structural slumps: The modern equilibrium theory of unemployment, interest, and assets: Harvard University Press.

Pini, P. (1997). Occupazione, tecnologia e crescita: modelli interpretativi ed eevidenze empiriche a livello macroeconomico'. Paper presented at Conference of Accademia Nazionale dei Lincei on 'Sviluppo tecnologico e disoccupazione: trasformazione della societa', Rome, 16-18 January 1997.

Rad, S. T. (2011). Jordan's Paradox of Growth without Employment: A Microcosm of the Middle East? Centre for development policy and research, Development Viewpoint, Number 65.

Sawtelle, B. (2007). Analyzing the Link between Real GDP and Employment: An Industry Sector Approach. Business Economics, 1, 46-54.

Sodipe, O. A. \& Ogunrinola, I. O. (2011). Employment and Economic Growth Nexus in Nigeria. International Journal of Business and Social Science, 2(11), 232 - 239.

Swane, A. \& Vistrand, H. (2006). Jobless Growth in Sweden? A Descriptive Study. Master's Thesis in International Economics and Business, Stockholm School of Economics.

Toda, H. Y. \& Yamamoto, T. (1995). Statistical inference in vector auto regressions with possibly integrated processes. Journal of Econometrics, 66, 225 - 250.

Walterskirchen, E. (1999). The Relationship between Growth, Employment and Unemployment in the EU. European Economist for an Alternative Economic Policy Workshop, Barcelona, Spain. http://www.memoeurope.unibremen.de/tser/Walterskirchen_24months.PDF Accessed 12 February 2013.

World Trade Organisation (WTO) (2013). Growth and jobs. http://www.wto.org/english/thewto_e/whatis_e/10ben_e/10b07_e.htm Accessed 1 February 2013

World Bank, World Development Indicators, (2011). http://www.indexmundi.com /facts/indicators/SL.UEM.TOTL.ZS/compare?country=bw\#country=za:sZ

Yogo, T. (2008). Growth and Employment in Sub Saharan Africa: Theoretical Evidence and Empirical Facts. Munich Personal RePEc Archive, Paper No 10474, http://mpra.ub.uni-muenchen.de/10474/ Accessed 11 February 2013

\section{Appendix A}

Table A1: VAR Lag Order Selection Criteria for employment and GDP: 2000Q1 to 2012Q3

\begin{tabular}{lllllll}
\hline Lag & LogL & LR & FPE & AIC & SC & HQ \\
\hline 0 & -528.6190 & NA & 21939320 & 22.57953 & 22.65826 & 22.60916 \\
1 & -362.0420 & 311.8890 & 21719.23 & 15.66136 & 15.89755 & 15.75024 \\
2 & -347.8337 & $25.39348^{*}$ & $14084.47^{*}$ & $15.22697^{*}$ & $15.62061^{*}$ & $15.37510^{*}$ \\
3 & -344.2857 & 6.039184 & 14398.93 & 15.24620 & 15.79731 & 15.45358 \\
4 & -343.6285 & 1.062618 & 16685.03 & 15.38845 & 16.09702 & 15.65509 \\
\hline
\end{tabular}

* indicates lag order selected by the criterion. LR: sequential modified LR test statistic (each test at $5 \%$ level). FPE: Final prediction error. AIC: Akaike information criterion. SC: Schwarz information criterion. HQ: Hannan-Quinn information criterion

Table A2: VAR Lag Order Selection Criteria for employment, GDP, Investment and Lending rate: 2000Q1 to 2012Q3

\begin{tabular}{lllllll}
\hline Lag & LogL & LR & FPE & AIC & SC & HQ \\
\hline 0 & -1175.002 & NA & $7.22 \mathrm{e}+16$ & 50.17030 & 50.32776 & 50.22955 \\
1 & -868.5487 & 547.7039 & $3.11 \mathrm{e}+11$ & 37.81058 & 38.59788 & 38.10685 \\
2 & -836.7920 & $51.35130^{*}$ & $1.61 \mathrm{e}+11^{*}$ & $37.14009^{*}$ & $38.55722^{*}$ & $37.67336^{*}$ \\
3 & -821.1693 & 22.60300 & $1.71 \mathrm{e}+11$ & 37.15614 & 39.20311 & 37.92643 \\
4 & -813.5089 & 9.779281 & $2.63 \mathrm{e}+11$ & 37.51102 & 40.18783 & 38.51832 \\
\hline
\end{tabular}

* indicates lag order selected by the criterion. LR: sequential modified LR test statistic (each test at $5 \%$ level). FPE: Final prediction error. AIC: Akaike information criterion. SC: Schwarz information criterion. HQ: Hannan-Quinn information criterion 